\title{
THE BRETON VERB ENDEVOUT AND THE FRENCH AVOIR: THE INFLUENCE OF DESCRIPTIVE GRAMMARS ON MODERN BRETON VERBAL SYSTEM
}

\author{
ANNA R. MURADOVA
}

\section{Introduction}

The present day Breton verbal system is represented in both descriptive and prescriptive grammars in a manner which follows the Latin and the French descriptive traditions. The problems of grammatical description that arise in some cases are due to the difficulties of framing the grammatical and syntactical constructions using a system of grammatical terms which is familiar for the author, but not always suitable for the purpose. As Plungian (2000) demonstrated, one of the difficulties of modern morphology is its terminology based on the Greek-Latin grammatical tradition and therefore problematic not only for non-IndoEuropean languages, but also for some categories of the Indo-European ones, e.g. Celtic languages.

As far as Breton is concerned, the influence of Latin and French can be seen in the emergence of the Middle Breton verb kaout/endevout 'to have' formed on the basis of bezañ/bout 'to be'. The need for kaout/endevout production treated as a separate verb instead of the bezañ/bout inflected form operation is not at all obvious for the Breton verbal system. Still, Breton lexicographers Reverend Maunoir, Gregor de Rostrenen and others had to ascribe to the forms such as am eus, ac'h eus etc. the same functions as those of the French avoir and of the Latin habere verbs following the paradigm of the Latin and French grammatical tradition.

\section{The problem of grammatical meanings compatibility}

Anyone trying to create a descriptive Breton grammar for academic or educational purposes will find it difficult to use well-known and understandable grammatical terms without any additional remarks. The verbal system of Breton illustrates this point well: the Breton language possesses not only the synthetic and analytic conjugation in the present, future, past perfect and imperfect tenses, but also has some special forms for habitual actions or states of bezañ/bout as well as the paradigm emaon, emaout, emañ etc. for space location also used in the construction emaon $o+$ infinitive similar to English constructions with -ing forms: 


\section{Emaoñ o tansal}

I am dancing

According to Plungian, the problem of compatibility of grammatical meanings in the modern typology has neither single nor simple solution:

Linguists give contradictory answers to the question whether different grammatical systems can be compared. In fact, the structuralist logic based on "meaningfulness" inside the system does not only deal with the possibility of comparison between the languages, but does not even need such a comparison. If an element of the language is what makes it different from other elements in the system, then it is not comparable with any other element in a different system (Plungian 2000: 233, my trans.).

Hence, describing Breton grammar using Latin and French grammatical framework and terms leads to numerous misunderstandings. Still, the sociolinguistic and extra-linguistic factors that brought about the increasing influence of French on Breton made it possible to justify the influence of Latin and French grammatical tradition not only on Breton descriptive grammars, but also on the Breton verbal system itself as far as the written language was concerned. This fact was pointed out by a number of twentieth century Breton creative writers who tried to produce a new standard of the Breton literature. Not only did they notice a large gap between the spoken language and its written form heavily influenced by Roman languages, but also the lack of adequate description of the spoken language grammar.

Modern grammarians describing modern Breton have to create new grammatical terms and a new descriptive approach. This approach is without a doubt appropriate for a linguist. The problem is that as such it is not applicable for practical purposes in so far as it is unintelligible for the non-linguist readers and learners. How can the new system of terms be communicated to those who were educated in French and have no notion of a descriptive system different from French grammar in its turn derived from the Latin tradition?

Different modern grammarians looked for different ways to solve this problem. F. Kervella wrote his 1947 Big Grammar of Breton (Yezhadur bras ar brezhoneg) in the vernacular using grammatical terms created on the basis of Breton stems. The problem was that the new terms such as ar verb, ar vogalenn, ar gesonenn were borrowed from French (le verbe, la voyelle, la consonne) or calqued from the French and Latin terminology: e.g. an anv-gwan 'verb participle', lit. 'the verbal adjective', 
an amzeriou eeun 'the simple tenses' etc. With no disrespect to the work by Kervella who created a remarkable book of reference for Breton teachers and students, we must point out that it represents an application of French linguistic framework to Breton rather than a new way of describing Breton according to its own grammatical structure.

A different way to describe the modern Breton grammar was proposed by J.-Y. Urien (1987). His aim was not to use the traditional Latin-based descriptive terms. He rather strove to set up a new descriptive system of terms resorting to the recent linguistic work on morphology. This academically oriented grammar was a step toward the understanding of an alternative way of grammatical description.

There still remains the problem that Urien's Grammar cannot be used in primary and secondary schools in so far as it is too complicated and therefore cannot be understood by young students. This way of describing modern Breton grammar system is certainly of great interest for modern scholars. But students and native speakers are still in need of a simple and clear grammar book. The existence of several modern descriptive and prescriptive grammars of several authors (see list of references below) does not mean that a good solution to the problem has been found.

Another difficulty for the authors of prescriptive grammars nowadays is that most of the students cannot learn Breton from their parents. In fact, modern grammarians aim their books at Francophones (or sometimes Anglophones) who have no intuitive knowledge of specific grammatical or syntactical constructions. So, the traditional way of description is more suitable because the learner will easily draw parallels between French (or English) and Breton grammatical features.

This approach is transparent from a pedagogical point of view, but entails some misunderstandings of grammatical and syntactic categories which are peculiar to the Breton language. Normally, such kind of mistakes made by the student learning a foreign language is normally corrected not by the teacher, but rather by native speakers in practice. However, in the context of contemporary situation existing in Modern Breton such mistakes do not tend to be corrected by the older generation of speakers. In the schools and universities students communicate in Breton strongly influenced by French and use grammatical and syntactical constructions that do not differ too much from the French ones.

Yet, it may not seem appropriate to think that the strong French influence on Breton grammatical system is a new phenomenon only due to the demographic and socio-linguistic changes of the twentieth century. 


\section{The background: Tradition of Breton descriptive grammar}

The tradition of creating Breton descriptive grammars and teaching Breton was set up at the beginning of the sixteenth century. The adjustment of the Breton grammatical categories to the Latin/French grammatical framework had begun largely before Breton lost its position as the everyday spoken language in the rural areas in Western (Lower) Brittany and before its area began to decrease.

I will look at the way such concepts as 'to be, to exist' and 'to have, to possess' are expressed. In French, the concepts are expressed by two verbs: être < Lat. esse and avoir < Lat. habere.

Both of these concepts were expressed in Old Breton by different forms of conjugation of the verb bot (but) < IE *bheu- (Fleuriot 1964: 320-4). The restricted number of Old Breton texts does not make it possible to make any conclusions about how the possessive constructions were marked in grammar and syntax.

In Middle Breton, the verb bout (an alternative infinitive form bezañ appeared later and became the most commonly used in Modern Breton, bout remained as a dialectal form) obtained both meanings of being/existing and of possession. According to R. Hemon (2000: 199), it is possible to speak about the appearance of possessive constructions based on $3 \mathrm{sg}$. pres. eus and personal pronouns. In fact, the paradigm of the new verb with a possessive meaning is similar to the Russian possessive construction у меня есть 'I have'.

The problem is now to understand whether these possessive forms of bezañ/bout were considered to be part of the paradigm of this verb by Breton speakers up to the Modern period. What complicates things is the fact that the verb attests several specific paradigms such as the consuetudinal and situative forms. Actually, unless one is aware of the fact that Roman languages have two separate verbs with two separate meanings 'to be' and 'to have', the idea of considering the possessive construction to be a separate verb does not seem to conform to the internal logic of the Breton language.

For instance, Russian does not need the verb 'to have, possess' (иметь ог владеть) in the following cases:
I have many friends
I have money
Уменя [есть] много друзей Уменя [есть] деньги.

Only dealing with translations of Latin and French texts into Breton one notices a striking difference between possessive constructions in Breton and in Roman languages. 
The first known descriptive grammar of Breton, An Donoet, was the translation of the Donatus Ars grammatica. It was carried out circa 1501 by an anonymous author from Plougreskant. The author used French grammatical terms which needed no translation into Breton: all those who could read and write had sufficient knowledge of Latin and French to understand them. An Donoet testifies that the Breton descriptive grammatical tradition was set up based on the Latin pattern with the employment of French terms. For many centuries, An Donoet was the template for grammarians, and an example to follow. ${ }^{1}$

The following attempts of describing Breton grammar attempted to make it as similar to An Donoet's description as possible. The authority of Latin authors and of the Latin language had a large influence on Breton clerics and their appreciation of the mother tongue: the Breton language grammatical system seems to have been considered by that time as a deviation from the proper Latin grammatical model (which was considered more appropriate).

A good grasp of Latin was the sign of good education much earlier than French was spoken in Breton towns. So, the Latin grammar became the universal pattern and Breton grammatical categories had to be described in the way which followed this pattern. All the features of the Breton grammar which did not have parallels in the Latin grammar were considered a deviation from the standard. This could have been a reason for the "standardisation" of the verbal system and the differentiation of possessive constructions based on the forms of bezañ/bout and the artificial formation of a new verb. The new verb has two artificially created infinitives: kaout, being a variety of the infinitive of the verb kavout 'to find', and endevout, constructed from $3 \mathrm{sg}$. fut. en devo 'he will have'. The derivation of the infinitive from the $3 \mathrm{sg}$. of a different personal form of the verb is not typical for Breton. Actually, no verb has such an infinitive. Another peculiarity of endevout is its absence in the spoken Breton. The infinitive kaout, meaning 'to find, to have' ${ }^{2}$ is largely employed in the colloquial speech and in literary works, but endevout does not appear in spoken Breton and seems to be a bookish word easily associated by native speakers with the heavy style of devotional literature, the so-called brezhoneg beleg, 'priests' Breton'.

\footnotetext{
${ }^{1}$ In Breton, the name Donatus became a common noun meaning a grammar manual.

2 The two meanings are very close, e.g. kaout amzer 'to find' (and, logically) 'to have time (for doing something)'.
} 


\section{The influence of the so-called 'priests' Breton'}

The main feature of this variety of written Breton is following the Latin pattern in grammar and syntax. The most frequently given example is the word pehini, pl. pere 'which' that does not exist in colloquial Breton and was invented by Breton-speaking priest in order to translate Latin prayers and saints' vitae. In his works, Yann Gevrenn $(2002,2003)$ points out not only the abusive use of French and Latin loanwords and Latin-like constructions in religious texts but the strong influence of priests' writing on the pre-modern and modern literature:

Se zo bet gwir betek an XIXvet kantved, ha gant Prosper Proux zoken, ha ne oa ket beleg, e kaver ar pozioù-mañ :

Adieu dit ma zi bihan, war leinig an dorgenn

Tachenn c'hlas war behini bugel e c'hoarien Gwez ivin ker bodenneg en disheol a bere, E-pad tommder an hanvioù e kousken da greiste. (Kimiad... )

E meur a ganaouenn all e kaver ivez ar pehini pe ar pere, deuet diwar ar galleg, ma vez ar memes ger evit ar goulenn lequel, lesquels hag ar relatif par lequel, sur lesquels,... etc... :

(Gevrenn 2002)

This is true up to the nineteenth century and one can find these constructions even in texts by a Breton poet Prosper Proux, who was not a priest:

Farewell, my little home on the top on a hill,

And the green lawn on which I used to play

And the bushy yew-trees under which

I stayed in shade by the hot summer days... (Kimiad)

In other songs we find pehini and pere coming from French like the interrogative lequel lesquels and relative par lequel and sur lesquels...etc.:

However, according to Y. Gevrenn, the French influence on the written Breton consists not only of introducing pehini, pere, and lexical borrowings. It also brings about the word order change resulting in the preference of SVO word order to that of VSO, and an abusive use of participles. The latter, according to Y. Gevrenn, seems not to be the result of French but rather of Latin influence. Translating Biblical texts from 
Vulgata into Modern Breton, such authors as J. M. Le Gall employed the following constructions: $o+$ verbal noun $(o+$ any verb in Y. Gevrenn's terminology) when a participle was used in Latin and French: in subordinate clauses (e.g. ablativus absolutus etc.) According to Y. Gevrenn, in many cases the use of verbal noun is ungrammatical, and is rarely found in the literary works of native Breton speakers. Examples from the New Testament translation that are incorrect from this point of view are provided by Y. Gevrenn as follows:

p. prés. Et extendens Jesus manum...

'Ha Jezuz, oc'h astenn e zorn (...), a lavaras..'

p.prés. Tunc surgens, imperavit...

'O sevel neuze, e kemennas...'

p.passé Et ingressus in templum...

'O vezañ aet en templ...'

Abl.abs. Et apertis thesauris suis...

'O vezañ digoret o zeñzorioù...'

sub. Ut cognovit mulier...

'Ur plac'h, o c'houzout...'

(Gevrenn 2002)

But his aim was not to blame the priests who created a written style very different from the colloquial language. The brezhoneg beleg in the nineteenth century was used in a specific way to mark the difference between the sacred and profane subjects. For example, the presence of a holy name in a phrase brought about a different word order:

Evel ma vije bet savet un urzh disheñvel evit frazennoù ma vez kaoz. enne eus un dra/un den sakr, evit lakaat ane'añ war-wel.

(Gevrenn 2002)

As a different word order was used in a phrase, it means its subject is a sacred thing/person, and it must be shown.

\section{Breton possessive constructions in modern grammars}

The first known complete Breton grammar in French was published in 1738. Its author Gregoire de Rostrenen based his work on the dictionary and grammatical appendix from the catechism Le Sacré-Collège de Jésus, written by Julien de Maunoir and published in 1659. However, De Rostrenen criticises his predecessor for trying to make the Breton syntax as similar to Latin as possible:

...Père Maunoir Jésuite a fait au siècle dernier, une Grammaire imparfaite, dont j'ai retiré quelque avantages, mais non de la Syntaxe, parce qu'elle est toute conforme à la Syntaxe Latine qui 
n'a aucun rapport à la syntaxe bretonne: mais il a beaucoup fait, si l'on considère que la Langue Bretonne lui étoit étrangère.

(Rostrenen 1738: 7)

... Father Maunoir the Jesuit made in the last century an imperfect Grammar from which I took some advantage but not from the Syntax because it is all like the Latin Syntax which has nothing in common with the Breton syntax: but he has done a lot, if we take into consideration that the Breton Language was foreign to him.

Gregoire de Rostrenen makes a clear difference between the verb bezañ (written as beza) and kaoutlendevout. The two of them he called auxiliary verbs. The distinction corresponds to the existence of two auxiliary verbs être and avoir in French. Since G. De Rostrenen, the tradition has remained and kaout/endevout is still regarded to be a separate verb; yet, modern authors emphasise the fact that this verb was created on the basis of bezañ (see F. Favereau's grammatical appendix to his dictionary):

Verbe avoir. Composé de bezañ/bout, précédé d'un pronom personnel (Favereau 1993: vii).

Verb to have. Composed from bezañ/bout and a preposed personal pronoun.

F. Kervella (1976: 206) refers to the etymology of bezan. Others, like Y. Desbordes, do not mention this fact but point out the defective character of kaout:

De tous les verbes de la langue, le verbe Kaout est le seul a développer une conjugaison unique que l'on utilise donc en toutes circonstances.

(Desbordes 1995: 63)

Out of all Breton verbs, the verb Kaout is the only one having a single way of conjugation used under any circumstances.

Meanwhile, in Breton there is a clear difference, not present in French, between the state of general possession and that of possessing something here and now:

(1) Arc'hant am eus 'I have money'

(I am wealthy and I own money, but at the moment of speech I possibly have no money with me at all).

(2) Arc'hant a zo ganin 'I have some money on me'

(in my pocket, in my wallet, but this does not mean I am wealthy). 
Taking into consideration a number of different conjugated forms of bezañ (including situational and habitual actions), it is not surprising to see that some of them are treated as separate verbs. The possessive constructions of bezañ are considered in grammars as a new verb kaout/endevout (see Rostrenen 1738: 7, Favereau 1993: vii, Desbordes 1995: 63). On the one hand, they are a result of the grammarians' activity which was influenced by Latin and French tradition of grammatical description. On the other hand, they can be perceived as an outcome of a natural trend in the development of the verbal system in Breton to use more and more analytic verbal constructions. ${ }^{3}$

In this regard, the influence of Latin and French patterns on the descriptive and prescriptive grammars of Breton and even on the brezhoneg beleg is not to be neglected. Nor should we neglect the fact that the development of the Middle Breton and pre-modern Breton verbal system made it possible for these changes to become understandable and acceptable for the speakers.

Institute of Linguistics, Moscow

\section{References}

Favereau, F., 1993, Geriadur brezhoneg - galleg, galleg - brezhoneg / Dictionnaire du breton contemporain bilingue, Montroules.

Jouitteau, M., et al., 2008, 'From mihi est to 'have' across Breton dialects', Rivista di Grammatica Generativa. Incontro di grammatica generativa, Padua, Italy: Uni Press, 33, Feb., 157-174.

Muradova, A., 2006, 'Analytic and synthetic verb conjugation in Modern Breton' (In Russian: 'Аналитическое и синтетическое спряжение глагола в современном бретонском языке'), in: Analytism in Languages of Different Types (in Russian: Аналитизм в языках различных типов: сорок лет спустя. К 100-летию со дня рождения В. Н. Яриевой. Материалы чтений памяти В. Н. Яриевой), $2^{\text {nd }}$ issue, Moscow, 217 - 224.

Poppe, E., 2005, 'Lexicalisation of transitive 'to have' in Breton and Cornish', A Companion in Linguistics, Nijmegen, 171-184.

Plungian, V. A., 2000, General Morphology (In Russian: Плунгян, B.A., Общая морфология), Moscow.

\footnotetext{
${ }^{3}$ For more detail, see Muradova 2006.
} 


\section{Descriptive grammars}

An Donoet, 1501, Plougreskant.

Desbordes, Y., 1995, Petite grammaire du Breton Moderne, Lesneven (3 édition).

Hemon, R., 2000, Yezhadur Istorel ar Brezhoneg, Lesneven.

Kervella, F., 1976, Yezhadur bras ar Brezhoneg, Brest (2 édition).

Fleuriot, L., 1964, Le Vieux Breton, Paris.

Percy Treasure, J., 1903, An Introduction to Breton Grammar, Carmarten.

de Rostrenen, G., 1738, Grammaire Françoise-Celtique ou FrançoiseBretonne, Rennes.

Ternes, E., 1970, Grammaire structurale du Breton de l'Ile de Groix, Heidelberg.

Urien, J.-I., 1987, La trame d'une langue. Le Breton, Lesneven.

\section{Electronic sources}

Gerven, Y., 'Eus ar brezhoneg beleg d'ar brezhonegoù lennegel', 28/04/2002 (accessed on 07.08.2011 at http://www.geocities.ws/yann_ gerven/pennadou2.html )

Gerven, Y., 'Herezh ar brezhoneg beleg ha penaos en em zizober dioutan Ar stumm: o + anv-verb' (29.03.2003) (accessed on 07.08.2011 at http://www.geocities.ws/yann_gerven/herezh_ar_brezhoneg_beleg.html) 